\title{
VESICO-APPENDICEAL FISTULA IN A MUCINOUS ADENOCARCINOMA OF THE APPENDIX
}

\section{Fístula vésico-apendicular em adenocarcinoma mucinoso do apêndice}

Ivan R B ORSO, Rodrigo Ambar PINTO, Marcus FKP RAMOS, Desidério Roberto KISS, Roberto Iglesias LOPES, Marcello COCUZZA, José Luis Borges de MESQUITA

Orso IRB, Pinto RA, Ramos MFKP, Kiss DR, Lopes RI, Cocuzza M, Mesquisa JLB. Vesico-appendiceal fistula in a mucinous adenocarcinoma of the appendix. ABCD Arq Bras Cir Dig 2008;21(1):44-6

ABSTRACT - Background - A rare case of vesicoappendiceal fistula secondary to mucinous adenocarcinoma of the appendix is presented. Case report - A 62-year-old man with a one year history of recurrent urinary tract infections. After two months he developed pneumaturia and fecaluria. An abdominal and pelvic computed tomography demonstrated a trans-mural mass in the posterior wall of the bladder with a vesicoenteric fistula leading to the terminal ileum. Laparotomy revealed a tumor arising from the appendix contiguous with the bladder posterior wall. The bladder was opened and a large fistula and tumor on the posterior bladder wall near the trigone was identified. Frozen pathological analysis showed a mucinous adenocarcinoma. En-bloc right hemicolectomy and partial cystectomy, preserving bladder trigone was performed. After manipulating the tumor, grossly leakage of mucinous materials occurred into the pelvic cavity. A peritoneal washing with a mytomicin solution at $42^{\circ} \mathrm{C}$ was then performed, to prevent peritoneal seeding. The patient had a prolonged postoperative ileus and was discharged at the $15^{\text {th }}$ day. Five months after the procedure the patient was recieving chemotherapy with 5-fluoracil and leucovorin and there was no signs of recurrent disease. Conclusion - The presentation with vesico-appendiceal fistula is extremely rare with only a few cases reported in the literature. Knowledge of different types of neoplasm and appropriate treatment allows the surgeon to provide patients optimal care referring to specialized centers whenever appropriate.

HEADINGS - Appendiceal cancer. Urinary bladder fistula. Adjuvant chemotherapy. Therapeutic hyperthermia.

\section{INTRODUCTION}

It's presented a rare case of vesico appendiceal fistula secondary to mucinous adenocarcinoma of the appendix. Patients with adenocarcinoma of the appendix are usually diagnosed with appendicitis, a right lower quadrant abscess, or a tumour mass and many are encountered as incidental findings at laparoscopy or laparotomy ${ }^{5,12}$. These tumors request different treatments depending on its histology, size, localization in the appendix, grade of invasion, perforation and metastasis. Evolution on adjuvant therapies gives patients and physicians good perspectives in prognosis.

\section{CASE REPORT}

A 62-year-old man presented with a 1-year history of dysuria and polaciuria, previously treated with oral antibiotics for recurrent urinary tract infections. He

Paper from the University of São Paulo School of Medicine - Hospital das Clínicas - São Paulo, SP, Brasil

Correspondence: Rodrigo Ambar Pinto - E-mail: roambar11@yahoo.com.br seeked for medical advice and had been submitted to an abdominal ultrasonography, urinary tract ultrasonography and excretory urography which were normal. After two months developed pneumaturia and fecaluria. At physical examination an abdominal mass was palpable at lower right abdominal quadrant. Rectal examination and prostate assessment were normal.

An abdominal and pelvic computed tomography was performed and demonstrated a trans-mural mass in the posterior wall of the bladder with a vesicoenteric fistula leading to the terminal ileum (Figure1). The CEA (carcinoembrionary antigen) level was 42 .

Laparotomy revealed a tumor arising from the appendix contiguous to the bladder posterior wall (Figure 2). The tumor had an intimous relation with right ureter. After opening the bladder a large fistula on the posterior wall near the trigone was identified. The tumor was mucin secreting and frozen pathological analysis showed an appendiceal mucinous adenocarcinoma. It was performed an en-bloc right hemicolectomy and partial cystectomy, preserving bladder trigone and bilateral double loop catheters were passed for adequate urinary drainage. During the procedure it was not observed tumoral peritoneal implants, but after manipulating the tumor, grossly leakage of mucinous materials occurred into the pel- 


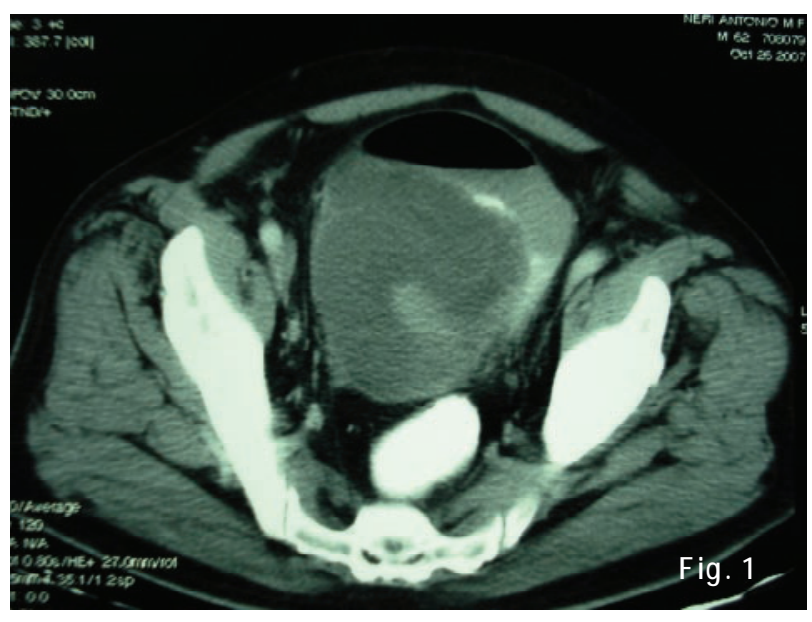

FIGURE 1 - CT showing a mass contiguous to the urinary bladder and fistula demonstrated by air inside the bladder

vic cavity. Than it was performed a peritoneal washing with a mytomicin solution at $42^{\circ} \mathrm{C}$, to prevent peritoneal seeding. Pathological examination demonstrated an exophitic, gelatinous mass with $17 \times 12 \mathrm{~cm}$ in diameter and vesicoenterical fistula formation (Figure 3). It was classified as a well differentiated mucinous adenocarcinoma of the appendix (Figure 4). Surgical margins were tumor-free and angiolymphatic invasion was not observed. Fifteen dissected lymph nodes were not involved by the tumor. Final pathological diagnosis was a pT4 pN0 pM0 appendiceal mucinous adenocarcinoma.

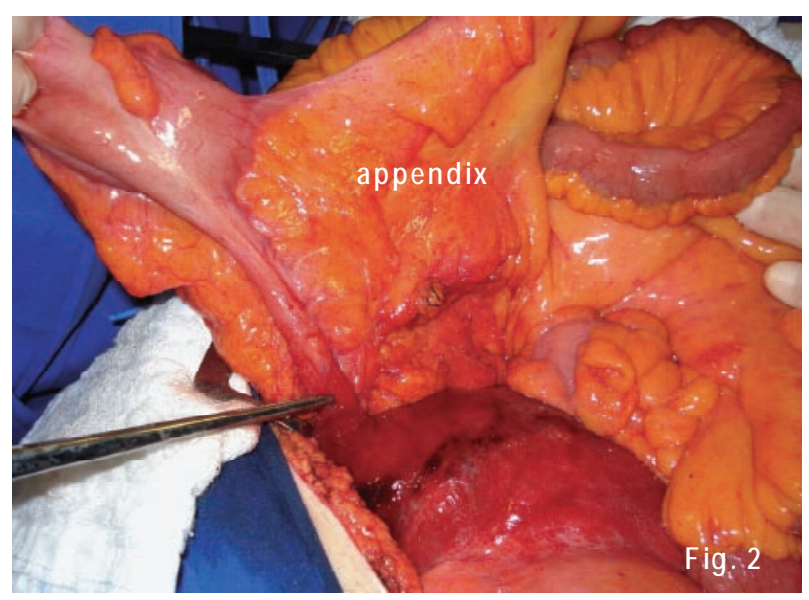

FIGURE 2 - Intra-operatory showing the mass arising from the appendix, invading the urinary bladder

The patient had a prolonged postoperative ileus and received periferical parenteral nutrition from de $5^{\circ}$ to the $11^{\circ}$ day when adequate oral intake was achieved. At $15^{\text {th }}$ day he was discharged. After two months, it was removed double loop catheters and cystoscopy did not reveal any residual lesion. At five months after the procedure, he was recieving chemotherapy with 5-fluoracil and leucovorin, with no image signs of peritoneal and the CEA remains in normal levels.

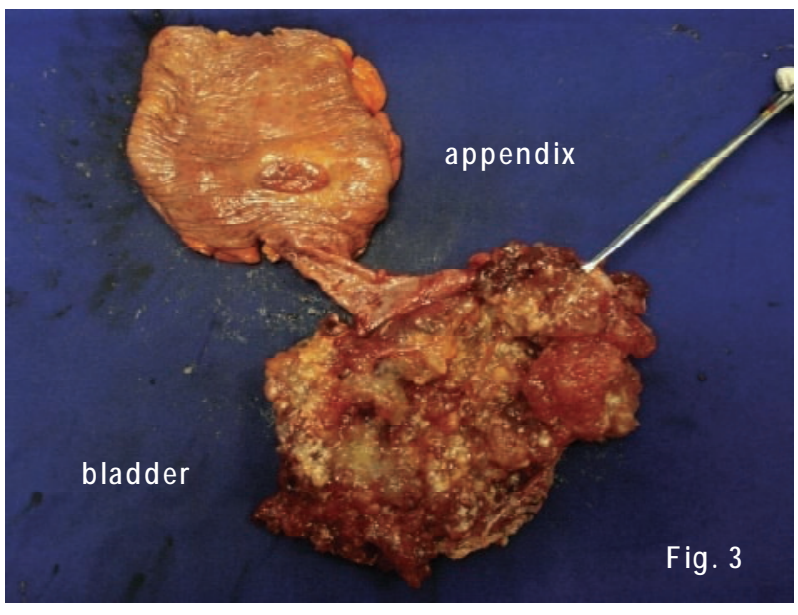

FIGURE 3 - Surgical specimen after resection

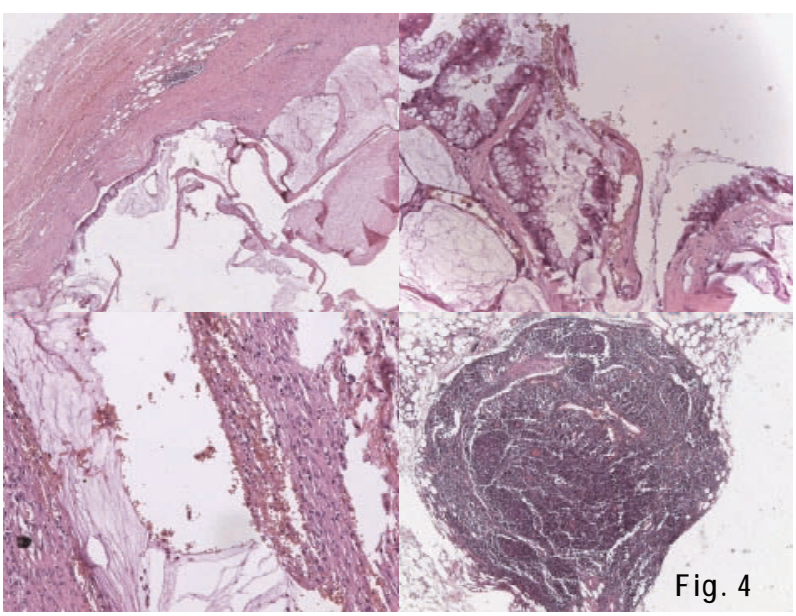

FIGURE 4 - Microscopy showing mucinous adenocarcinoma and bladder invasion

\section{DISCUSSION}

Vesicoenteric fistula is usually a complication of an inflammatory or neoplasic process. Common causes include diverticulitis (65-75\%), malignant disease (10-15\%) and Crohn's disease (5-6\%). Presenting symptoms are pneumaturia $(52-77 \%)$, fecaluria $(36-51 \%)$ and urinary tract infection symptoms (44-45\%)11. Investigation modalities are usually poor, with abdominal CT being the most useful imaging modality. Although cystoscopy can be performed, it is diagnostic in only $30-40 \%$ of cases ${ }^{8}$.

Appendiceal carcinomas are rare with an incidence of 0,12 cases per $1,000,000$ people per year. It is estimated that appendiceal cancer is found in $1 \%$ of all appendectomy specimens ${ }^{6}$.

Patients with adenocarcinoma of the appendix are usually diagnosed with appendicitis, a right lower quadrant abscess, or a tumour mass ${ }^{5,12}$. Rarely the tumor can invade the abdominal wall with an enterocutaneous fistula or the urinary bladder with an enterovesical fistula, as shown in this case. International literature report only nine cases of 
vesico-appendiceal fistulas derived from mucinous appendiceal adenocarcinomas until present data ${ }^{1,2,3,4,8}$. This type of tumor usually perforates before diagnosis and may spread to the peritoneal cavity, producing mucinous intraperitoneal ascites, resulting in the pseudomixoma peritonei ${ }^{7}$.

The initial assessment of the incidental appendiceal tumor includes assessment of tumor size, involvement of the base of the appendix or the mesoappendix and its perforation?

If the tumour is confined to the appendix, smaller than $2 \mathrm{~cm}$, without evidence of mesoappendiceal or basal involvement, appendicectomy is the appropriate treatment. An emergency cryostat sectioning should be done and if an invasive non-mucinous adenocarcinoma of the appendix is shown a right hemicolectomy can double the survival achieved with routine appendicectomy ${ }^{1}$. In tumours larger than $2 \mathrm{~cm}$ or with invasion of the base or mesoappendix, a right hemicolectomy should be performed ${ }^{7}$.

If the appendix has ruptured just before removal or during the operation, it is important to remove all free mucin and perform meticulous peritoneal toilet. After resection, and with the abdomen opened, the peritoneal cavity could be washed with warm $\left(41-5^{\circ} \mathrm{C}\right)$ mitomycin solution to avoid peritoneal seeding. Such patients and those who present with a perforated mucinous neoplasm, without evidence of any extra-appendiceal spread, are at risk of developing pseudomixoma peritonei and should be followed up carefully. CT of the abdomen and pelvis and tumour markers (CEA, CA 125 and CA 19.9), provide baseline measure- ments ${ }^{7}$. At the present case the leakage of peritoneal cavity led to perform the warm mitomycin solution wash. Follow up doesn't show any sign of recurrence, and the patient is been treated with systemic chemotherapy.

Perforated mucinous neoplasm of the appendix with pseudomyxoma peritonei syndrome is best treated by complete removal of tumor (peritonectomy) and hiperthermic intraperitoneal chemotherapy [mitomycin solution $\left(41-5^{\circ}\right.$ C) during surgery and 5-fluoroucil for four to five days after surgery] ${ }^{9}$.

Right hemicolectomy, without intraperitoneal chemotherapy or complete removal of the tumor, at an initial procedure for a perforated mucinous adenocarcinoma with peritoneal involvement, results in no survival benefit. In this cases the peritoneal cavity should be thoroughly washed out, and the patient should be referred to an appropriate specialized center for definitive treatment ${ }^{7,9,12}$.

\section{CONCLUSION}

Appendiceal neoplasms are uncommon and consists in an heterogeneous group of pathologies. Many present as appendicitis, but some are encountered as incidental findings at laparoscopy or laparotomy. The presentation with vesico-appendiceal fistula is extremely rare with only a few cases reported in the literature. Knowledge of the different types of neoplasm and appropriate treatment allows the surgeon to provide patients optimal care.

Orso IRB, Pinto RA, Ramos MFKP, Kiss DR, Lopes RI, Cocuzza M, Mesquisa JLB. Fístula vésico-apendicular em adenocarcinoma mucinoso do apêndice. ABCD Arq Bras Cir Dig 2008;21(1):44-6

RESUMO - Introdução - Apresenta-se raro caso de fístula vésico-apendicular secundária a adenocarcinoma mucinoso do apêndice. Relato do caso - Paciente masculino de 62 anos com história de um ano de infecções urinárias de repetição. Após dois meses desenvolveu pneumatúria e fecalúria, sendo indicada tomografia computadorizada de abdômen que mostrou massa trans-mural na parede da bexiga, com fistula vésico-entérica para região do íleo terminal. A laparotomia revelou tumoração surgindo do apêndice cecal, em continuidade com a parede posterior da bexiga. A mesma foi aberta, sendo identificada grande fistula e material tumoral até próximo ao trígono vesical. A biópsia de congelação identificou adenocarcinoma mucinoso. Realizada hemicolectomia associada à cistectomia parcial em bloco, com preservação do trígono vesical. Houve extravasamento de mucina para a cavidade pélvica pela manipulação. Optado por lavagem peritoneal com solução de mitomicina a $42^{\circ} \mathrm{C}$ para prevenir disseminação peritoneal. O paciente evoluiu com íleo prolongado pós-operatório, tendo alta hospitalar no $15^{\circ}$ dia. Cinco meses após o procedimento encontravase em quimioterapia com 5-fluouracil e leucovorin, sem sinais de doença recidivante. Conclusão - A presença de fístula vésico-apendicecal é extremamente rara, tendo poucos casos relatados na literatura. $\mathrm{O}$ conhecimento dos diferentes tipos de neoplasias e seus tratamentos adequados permite ao cirurgião oferecer melhor cuidado ao paciente.

DESCRITORES - Câncer do apêndice. Fístula urinária. Quimioterapia adjuvante. Hipertermia terapêutica.

\section{REFERENCES}

1. Chen KTK, Spaulding RW.Appendiceal carcinoma masquerading as primary bladder carcinoma. The Journal of Urology 1991;145:821-822

2. Dahms SE, Hobenfellner M, Eggersmann C, LenpilA. Appendix carcinoma invading urinary bladder. Urol Int 1997;58(2):124-127

3. Henry R, Bracken RB, AyalaA. Appendiceal carcinoma mimicking primary bladder cancer. The Journal of Urology 1980;123:590-591

4. Ikeda I, Miura T, Kondo I. Case of vesico appendiceal fistula secondary to mucinous adenocarcinoma of the appendix. The Journal of Urology 1995;153:1220-1221

5. Iswariah H, Metcalfe M, Darren L, Maddern GJ. Mucinous cystoadenoma of the appendix: ANZ J Surg 2004;74:918-919

6. McGory ML, Maggard MA, Kang H, O'Connell JB, Ko CY. Malignancies of the appendix: Beyond case series reports. Diseases of the Colon \& Rectum 2005;48:2264-2271

7. Murphy EMA, Farquharson SM, Moran BJ. Management of an unexpected appendiceal neoplasm. British Journal of Surgery 2006;93:783-792

8. Paola M, Stockwell WS. Appendico-vesical fistula due to an Appendix Abscess with associated goblet cell carcinoid of the appendix. British Journal of Urology $1976 ; 48: 436$
9. PortillaAG, Cendoya I, Tejada IL, Olabarria I, Magrach L, Lecea CM, GilA, Valdovinos M, Larrabide I, Alegria NR, Ulibarrena MA. Bases y fundamentos del tratamiento de la carcinomatosis peritoneal por cancer colorectal. Cir Esp 2005;77(1):6-17

10. Sato VT, Detry O, Polus M, Thiry A, Detroz B, Mawja S, Hamoir E, Defechereux T, Coimbra C, Roover A, Meurisse M, Honoré P. Carcinoid tumor of the appendix: A consecutive series from 1237 appendectomies. World J Gastroenterol 2006;12(41):6699-6701

11. Smaniotto B, Orso IRB, Marques AS, Maranhão BSA, Lages LB, Lima T. Fístula entero vesical na doença de Crohn. Rev Med 2003;3:23

12. Sugarbaker PH. New standard of care for appendiceal epithelial neoplasms and pseudomyxoma peritonei syndrome. Lancet Oncol 2006;7:69-76

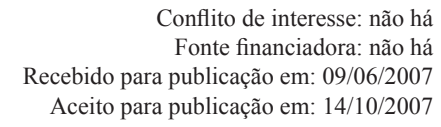

Conflito de interesse: não há Aceito para publicação em: 14/10/2007 